\title{
PENGEMBANGAN PRODUK BUBUK BUAH MANGGA (MANGIFERA INDICA L) INSTAN
}

\section{THE PRODUCTION OF MANGO (MANGIFERA INDICA L) POWDER}

\author{
Sri Agustini dan Patoni A Gafar \\ Balai Riset dan Standardisasi Industri Palembang \\ JI. Perindustrian II No. 12 Sukarami Km. 9 Palembang 30152 \\ e-mail : sragustini@yahoo.com
}

Diterima: 23 Januari 2018 ; Direvisi: 9 Mei 2018 - 21 Juni 2018; Disetujui: 28 Juni 2018

\begin{abstract}
Abstrak
Penelitian ini merupakan bagian dari penenlitian pembuatan kopi instan rasa buah. Penelitian bertujuan untuk mendapatkan sari buah mangga instan yang dapat diterapkan pada industri kecil. Penelitian menggunakan rancangan acak lengkap dengan konsentrasi bahan pengisi sebagai perlakuan dengan 3 replikasi. Mangga yang digunakan dalam penelitian ini adalah mangga harum manis dengan bahan pengisi gula pasir pada konsentrasi $20 \%, 25 \%$ dan 30\%. Pengujian kadar air menggunakan metode gravimetri, kadar vitamin C dengan metode titrimetri, kelarutan dalam air panas dan air dingin serta pengujian ALT. Hasil penelitian menunjukkan bahwa bubuk sari buah mangga hasil dari semua perlakuan memiliki kadar air $<4 \%$ dan angka lempeng total $<100 \mathrm{cfu}$. Kadar asam askorbat tertinggi diperoleh pada perlakuan $20 \%$ gula yaitu $2250 \pm 160$ ppm. Uji kesukaan dilakukan oleh 12 orang panelis meliputi warna, aroma dan rasa. Untuk tingkat kesukaan tertinggi terhadap warna didapatkan pada perlakuan $20 \%$ gula yaitu $3,5 \pm 0,67$; sedangkan tingkat kesukaan tertinggi untuk aroma dan rasa diperoleh pada perlakuan $20 \%$ gula yaitu $3,4 \pm 0,51$ dan $3,9 \pm 0,67$.
\end{abstract}

Kata kunci : bubuk sari mangga, konsentrasi gula, organoleptik

\section{Abstract}

This research was part of research on manufacturing of fruit flavored instant coffee. The research was intended to obtain mangoes powder which can be applied to small industries. Research using randomized complete design with concentration of fillers as the treatment with 3 replication. Mangoes used in this research were mangga harum manis and fillers used were sugar at a concentration of $20 \%, 25 \%$ and $30 \%$. The physicochemical all treatment have water content below 4\%, and total plate count below $100 \mathrm{cfu}$. While the highest ascorbic acid content was obtained from $20 \%$ sugar namely $2,250 \pm 160 \mathrm{ppm}$. The level of consumer preferences were analyzed following the procedure organoleptic test by 12 panelists including color, aroma and taste. The highest score preference level of color was produced by $20 \%$ sugar that was equal to $3.5 \pm$ 0.67 ; while the higest score for aroma and taste by $25 \%$ sugar that was equal to $3.4 \pm 0.51 ; 3.9 \pm 0.67$ respectively.

Keywords: manggo powder, sugar concentration, organoleptic test.

\section{PENDAHULUAN}

Mangga (Mangivera indica L.) merupakan salah satu buah tropis penting di Indonesia, dan dapat dijumpai di hampir semua wilayah/daerah karena banyak tumbuh dan mempunyai rasa khas.

Buah mangga mengandung nutrisi penting seperti karbohidrat, gula, serat, lemak, protein, beta karoten, kalium, vitamin A, B6, dan vitamin C (Leghari et al., 2013). Mangga merupakan buah musiman dan tergolong buah yang mudah rusak. Kerusakan dapat terjadi pada berbagai tingkatan penanganan, misalnya penangan saat panen, distribusi dan transportasi serta terbatasnya penyimpanan selama puncak masa panen (Caparino et al., 2012; Assous, 2014). Kadar air yang tinggi menyebabkan mangga cepat rusak karena mikroba, reaksi kimia dan reaksi enzimatis (Nadirah, 2009). Selain itu mangga termasuk buah yang tidak 
tahan lama disimpan pada suhu kamar, sehingga cepat mengalami kerusakan ( Syafutri et al., 2005; APO, 2006; Wijana, Rajkumar, 2006; Hii et al., 2011). Pengolahan kelebihan pasokan mangga saat puncak musim menjadi berbagai jenis produk olahan seperti bubuk sari mangga dapat menjadi nilai tambah dan alternatif solusi penanganan ketersediaan pasokan setiap tahun. Selain itu pengolahan buah menjadi sari buah instan dapat memanfaatkan buah hasil sortiran karena kesalahan penanganan (Wong et al., 2015).

Di lain sisi industri pengolahan kopi instan telah menghasilkan berbagai varian produk kopi mix, diantaranya kopi instan rasa jahe, kopi instan ginseng, kopi mix (kopi + gula + creamer) dan lain telah dapat diterima secara luas oleh konsumen. Ini berarti bahwa pengembangan produk kopi beraroma buah mempunyai potensi untuk dapat dikembangkan dan diterima oleh konsumen.

Pengembangan produk kopi mix instan beraroma buah melibatkan teknologi proses yang sederhana, yaitu pembuatan bubuk kopi instan dan bubuk mangga instan. Dengan teknologi ini proses pembuatan kopi instan rasa buah akan menjadi lebih sederhana dan dapat diterapkan pada skala industri rumah tangga.

Pembuatan kopi instan secara sederhana dapat dilakukan dengan cara menyeduh bubuk kopi dengan air mendidih selama 2 menit kemudian disaring menggunakan saringan 100 mesh. Hasil saringan kemudian dikeringkan dengan alat pengering yang mempunyai pengaduk dan blower sampai kadar air tertentu kemudian ditambahkan gula pasir sambil terus diaduk sampai terbentuk kristal padat yang kering.

Untuk mendapatkan kopi instan aroma mangga, maka buah mangga harus diproses terlebih dahulu menjadi bubuk mangga instan. Menurut Paramita (2012) bubuk sari buah mangga dapat digunakan sebagai penambah cita rasa pada berbagai jenis makanan dan minuman misalnya campuran dalam makanan bayi dan anak, roti dan kue, jelly, puding, serta penambah rasa pada es krim dan yoghurt. Pembuatan bubuk buah mangga dapat dilakukan dengan cara mengeringkan sari buah mangga.

Pengeringan pada prinsipnya adalah menurunkan kadar air pada sari buah sampai pada batas tertentu sehingga pertumbuhan mikroba dan aktivitas enzim dapat dicegah (Jangam et al., 2014; Mishra et al., 2014). Sari buah dapat diubah menjadi partikel bubuk menggunakan berbagai metode pengeringan, misalnya dengan penjemuran, pengeringan oven, pengeringan beku, pengeringan vakum dan pengeringan semprot dan pengeringan microwave (Bala et al., 2003; Gabas et al., 2007; Jittanit et al., 2010; Botha et al., 2012; Chong dan Law, 2011).

Pengeringan dengan penjemuran dan pengeringan oven merupakan metode pengeringan yang paling sering digunakan oleh industri rumah tangga karena teknologinya paling sederhana. Metode penjemuran digunakan karena paling sederhana dan tidak memerlukan peralatan khusus. Kelemahan penggunaan metode penjemuran adalah suhu pengeringan tidak konstan dan waktu yang dibutuhkan untuk pengeringan sangat tergantung pada cuaca. Pada musim hujan pengeringan dengan penjemuran tidak dapat dilakukan.

Dalam penelitian ini dilakukan pembuatan bubuk mangga instan dengan metode penjemuran. Perlakuan dalam penelitian ini adalah konsentrasi bahan pengisi yaitu gula. Pemilihan gula sebagai bahan pengisi bertujuan untuk mendapatkan sari buah mangga instan yang tahan lama. Menurut BeMiller dan Whistler (2008) gula memiliki daya larut dan daya mengikat air yang tinggi yang menyebabkan gula sering digunakan dalam pengawetan bahan pangan. Selain itu Standar Nasional Indonesia mendefinisikan bubuk sari buah instan 
sebagai campuran dari ekstrak sari buah, gula pasir dan bahan tambahan makanan lain yang diizinkan (SNI).

\section{BAHAN DAN METODE}

\section{Bahan}

Bahan yang digunakan dalam pembuatan bubuk buah mangga instan terdiri dari mangga harum manis yang matang yang didapat dari pasar tradisional di kota Palembang, gula pasir, dan akuades, serta bahan kimia untuk analisa kandungan asam askorbat (Vitamin C) dan angka lempeng total $(A L T)$.

\section{Peralatan}

Peralatan yang digunakan meliputi juicer, saringan 100 mesh, nampan, timbangan dan oven, neraca analitis, peralatan uji mikrobiologi dan gelas ukur.

\section{Metode}

Metode penelitian menggunakan rancangan acak lengkap dengan penambahan gula sebagai perlakuan yang terdiri dari $20 \%, 25 \%, 30 \%$. Hasil dari perlakuan dilakukan pengamatan terhadap, kadar air, asam askorbat dan angka lempeng total, kelarutan dan uji sensoris. Setiap perlakuan dilakukan 3 replikasi. Data disajikan dalam bentuk rerata \pm standar deviasi.

Pembuatan bubuk mangga instan dilakukan dengan cara sebagai berikut :

a. $1 \mathrm{~kg}$ daging mangga harum manis diambil sarinya dengan menggunakan juicer.

b. Sari buah mangga yang didapat kemudian disaring menggunakan saringan 100 mesh.

c. Ditambahkan gula pasir sesuai perlakuan yaitu $(20 \%, 25 \%$ dan $30 \%$ dari berat daging buah)

d. Campuran sari buah dan gula dipanaskan hingga semua gula terlarut. e. Tuang campuran di atas loyang setebal 0,5 cm

f. Keringkan dengan cara menjemur di bawah sinar matahari sambil di aduk sesekali hingga terbentuk gumpalan kristal yang kering.

g. Hancurkan gumpalan yang terbentuk menggunakan blender.

Pengukuran kadar air dan kadar abu menggunakan metode gravimetri. Pengukuran asam askorbat menggunakan metode titrimetri. Pengujian angka lempeng total digunakan metoda AOAC.

Solubility dianalisa berdasarkan SNI bubuk buah instan. $1 \mathrm{~g}$ sampel bubuk buah di larutkan dalam $300 \mathrm{ml}$ air distilasi yang dipanaskan pada suhu $70^{\circ} \mathrm{C}$, menggunakan magnetic stirrer pada kecepatan skala 6 . Waktu yang dibutuhkan untuk melarutkan sampel secara sempurna dicatat.

Uji sensoris dilakukan untuk menentukan perlakuan yang paling disukai oleh panelis, menggunakan 12 orang panelis. Analisis sensoris yang dilakukan meliputi rasa, warna dan aroma bubuk sari buah mangga. Metode analisa sensoris yang digunakan adalah uji kesukaan dengan menggunakan ranking test hedonic. Skor penilaian terdiri dari nilai 1 sampai 5 , dimana nilai 1 adalah nilai terendah ( amat sangat tidak suka) dan 5 adalah nilai tertinggi (sangat suka sekali). Data hasil penilaian panelis dilakukan pengolahan secara statistik menggunakan uji Friedmans. Perlakuan yang terbaik memiliki rasa, warna dan aroma yang paling disukai oleh panelis.

\section{HASIL DAN PEMBAHASAN}

\section{Rendemen}

Rerata rendemen sari mangga instan hasil perlakuan berkisar antara 27,2 \pm $1,32 \%$ untuk perlakuan penambahan gula $20 \%$ sampai $36,2 \pm 1,86 \%$ untuk perlakukan $30 \%$. Rendemen sari buah 
mangga sangat dipengaruhi oleh konsentrasi bahan pengisi (gula) yang digunakan. Semakin banyak bahan pengisi yang digunakan, semakin tinggi rendemen yang didapat. Hal ini sesuai dengan Endang dan Prasetyastuti (2010), yang menyatakan bahwa jumlah bahan pengisi yang ditambahkan akan mempengaruhi rendemen karena semakin banyak filler akan semakin besar total padatan yang diperoleh.

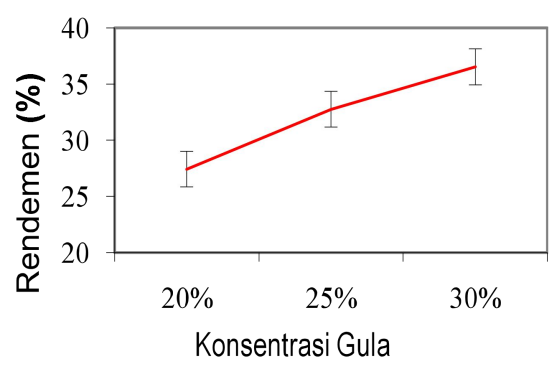

\section{Gambar 1. Rendemen}

\section{Kadar Air}

Gambar 2 menunjukkan bahwa kadar air bubuk mangga instan yang dihasilkan berkisar antara 2,2 $\pm 0,425 \%$

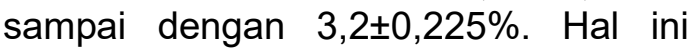
sesuai dengan Sangamitrha et al. (2014) yang menyatakan bahwa selama pemanasan kandungan air pada bahan dapat diturunkan hingga $1-5 \%$, yang mana pada level kadar air tersebut mampu mencegah kerusakan karena aktivitas mikroba serta reaksi enzimatis yang tidak diinginkan.

Menurut SNI 01-4320-1996 syarat mutu minuman bubuk, persyaratan kadar air minuman bubuk yaitu $3,0-5,0 \%$. Jika merujuk pada persyaratan SNI untuk syarat air minuman bubuk, maka semua perlakuan memenuhi persyaratan kadar air yang ditetapkan. Secara Mikrobiologi bubuk sari buah yang mengandung kadar air kurang dari 10\% tergolong aman, karena mikroba akan sulit tumbuh dan berkembang pada kadar air kurang dari 10\% (Sangamitrha et al., 2014; Wong et al., 2015).
Kadar air bubuk sari buah mangga perlakuan penambahan gula $30 \%$ paling rendah jika dibandingkan dengan perlakuan lainya. Hal ini disebabkan karena gula pasir memiliki kadar air maksimum $0,1 \%$ (SNI3140:2010, Gula kristal - Bagian 3 : putih) sehingga dapat menurunkan kadar air bahan campuran. Hal ini sesuai dengan Fitronin et al. (2003) dan Rakhmad (2007) yang menyatakan bahwa bahan pengisi akan meningkatkan jumlah padatan terlarut dalam sari buah sehingga jumlah air yang harus diuapkan menjadi menurun.

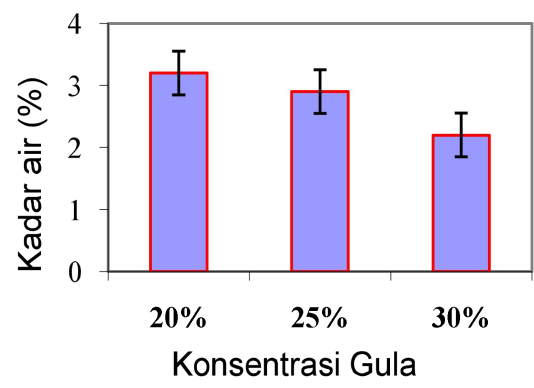

Gambar 2. Kadar air

\section{Kadar Asam Askorbat}

Kadar asam askorbat pada bubuk mangga instan yang dihasilkan berkisar antara 1,43 $\pm 0,24 \%$ sampai $2,25 \pm 0,16 \%$. Kadar asam askorbat tertinggi diperoleh pada perlakuan penambahan gula sebesar $20 \%$ dan terendah pada perlakuan penambahan gula $30 \%$. Hal ini disebabkan karena gula sebagai bahan pengisi tidak mengandung asam askorbat sehingga semakin banyak bahan pengisi maka kadar asam askorbat pada bubuk sari buah yang dihasilkan semakin menurun. Hal ini sesuai dengan Fennema (1995) yang menyatakan bahwa gula ketosa dapat meningkatkan laju degradasi anaerobik terhadap asam askorbat. Selain itu penurunan kadar asam askorbat terjadi karena reaksi oksidasi selama pengolahan. Asam askorbat mudah teroksidasi selama pengolahan dan penyimpanan. 
Asam askorbat (Vitamin C) merupakan senyawa seperti karbohidrat yang mempunyai sifat pereduksi dan asam dari gugus 2,3 enediol. Asam askorbat merupakan senyawa polar sehingga dapat larut dengan mudah dalam air dan tidak larut dalam pelarut non polar. Selain sebagai nutrisi esensial, asam askorbat memiliki sifat pereduksi dan sifat anti oksidan (Varvara et al., 2016).

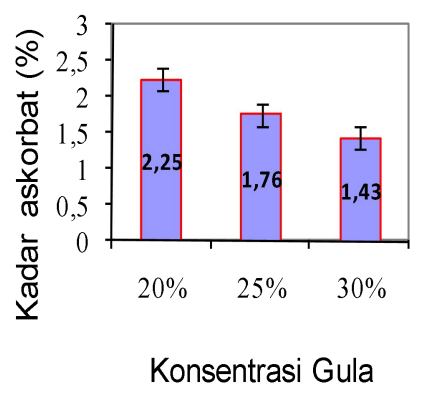

Gambar 3. Kadar asam askorbat

Sifat fungsional lain dari asam askorbat adalah (a) melindungi senyawa yang mudah teroksidasi dengan mengurangi free radical scavenging dan oxygen scavenging, (b) menghambat pembentukan nitorsamin pada daging olahan, (c) mereduksi ion logam (Gregory III, 2008).

\section{Kadar Abu}

Kadar abu menunjukkan campuran dari komponen anorganik atau mineral yang terdapat pada suatu bahan makanan olahan (Harris, 2017). Bahan pangan terdiri dari $96 \%$ bahan organik dan air, sedangkan sisanya merupakan unsur-unsur mineral, yang juga dikenal sebagai zat organik atau kadar abu (Simanjuntak,2014; Sulfiani et al., 2017). Bahan-bahan organik dalam proses pembakaran akan terbakar tetapi komponen anorganiknya tidak, karena itulah disebut sebagai kadar abu. Mineral dalam abu berupa oksida logam, sulfat, fosfat, nitrat, klorida, dan halida lainnya (Miller, 2008).

Kadar abu pada makanan berkaitan dengan kandungan mineral dan adanya kontaminasi kotoran. Mineral yang paling banyak pada tumbuhan adalah kalium, kalsium, magnesium, besi, phosphor, sulfur, dan nitrogen (Sulfiani et al., 2017).

Kadar abu pada bubuk mangga instan yang dihasilkan berkisar antara $0,17 \pm 0,02 \%$ sampai $0,24 \pm 0,03 \%$. Kadar abu tertinggi diperoleh pada perlakuan penambahan gula sebesar $20 \%$ dan terendah pada perlakuan penambahan gula $30 \%$.

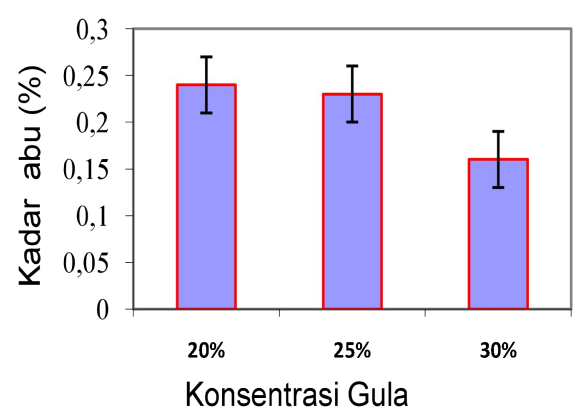

Gambar 4. Kadar abu

\section{Solubility}

Hasil pengujian solubility menunjukkan bahwa semua bubuk sari buah mangga instan hanya membutuhkan waktu kurang dari 3 menit untuk dapat larut di dalam air hangat.

\section{Angka Lempeng Total.}

Pengujian cemaran mikroba dimaksudkan untuk memberikan gambaran tentang kondisi higienis dan untuk menilai keamanan dan mutu mikrobiologi dari bubuk mangga instan yang dihasilkan. Pengujian ALT dimaksudkan untuk menunjukan tingkat mikro organisme dalam produk (Maturin dan Peeler, 2001; Yunita et al., 2015). Kehadiran ALT dalam makanan dalam 
jumlah diatas batas (limit) tertentu, merupakan pertanda bahwa makanan telah terpapar dengan kondisi-kondisi yang memungkinkan berkembang biaknya mikroba patogen (BPOM, 2008). Peningkatan angka lempeng total di atas batas yang ditentukan menunjukan penurunan kebersihan, stagnasi atau pembentukan biofilm (CAC/RCP 331985).

Hasil pengujian menunjukkan bahwa ALT bubuk mangga instan hasil semua perlakuan kurang dari 100 cfu (<100 cfu). Ini menunjukkan bahwa perlakuan penjemuran mampu menekan besaran angka lempeng total pada bubuk sari buah mangga yang dihasilkan. Hal ini disebabkan karena kadar air bubuk sari buah mangga instan yang dihasilkan kurang dari 10\% (berkisar antara $2,2 \pm 0,425 \%$ sampai dengan $3,2 \pm 0,225 \%$ ). Pada kadar air kurang dari $10 \%$ mikroba akan sulit untuk tumbuh dan berkembang (Wong et al.,2015). Selain itu penggunaan gula sebagai bahan pengisi dalam pembuatan bubuk sari buah juga memberikan keuntungan tersendiri, karena gula (sukrosa) merupakan bahan makanan yang aman secara mikrobiologi, sehingga gula sering digunakan sebagai bahan pengawet makanan. Penambahan gula pada pembuatan bubuk sari buah instan menyebabkan aktivitas air (aw) menjadi turun akibatnya pertumbuhan organisme dapat dihambat. Konsentrasi gula yang cukup tinggi pada olahan pangan dapat mencegah pertumbuhan mikrobia melalui mekanisme osmosis. Tekanan osmosis yang tinggi pada bahan menyebabkan air dari sel bakteri/mikroba berdifusi keluar sehingga bakteri/mikroba mengalami dehidrasi dan terjadi plasmolisis ( Gianti dan Evanuraini, 2011)

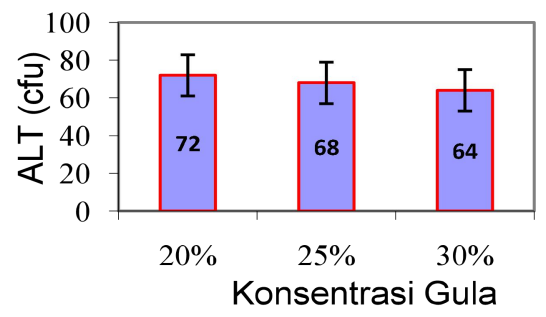

Gambar 5. Angka lempeng Total

Per KBPPOM No. HK. 00.06.1.52.4011 tahun 2009 menetapkan ALT sebesar $3 \times 10^{3}$ koloni/g untuk serbuk minuman (berperisa atau tidak berperisa, tradisional dll). Dengan merujuk persyaratan tersebut, maka semua sari buah mangga instan hasil perlakuan telah memenuhi persyaratan.

\section{Uji Sensoris}

Untuk parameter rasa panelis memberikan skor nilai terendah pada perlakuan penambahan gula pasir $30 \%$ dan skor tertinggi pada konsentrasi gula pasir 20\% yaitu 3,9 (manis khas mangga). Perlakuan penambahan gula pasir $30 \%$ menyebabkan rasa bubuk buah mangga yang dihasilkan didominasi oleh rasa manis gula sehingga menutupi rasa khas buah mangga. Dari hasil uji organoleptik kesukaan panelis terhadap bubuk sari buah mangga terlihat bahwa panelis lebih menyukai rasa bubuk sari buah mangga perlakuan penambahan $20 \%$. Uji Freedman-Conover menunjukkan bahwa pengaruh konsentrasi gula tidak signifikan terhadap tingkat kesukaan rasa bubuk buah mangga. Tabel 1 menunjukkan bahwa perlakuan penambahan $20 \%$ berbeda tidak nyata dengan perlakuan $25 \%$ dan $30 \%$. 
Tabel 1. Hasil Uji Kesukaan bubuk sari buah mangga

\begin{tabular}{lllllll}
\hline Kode & \multicolumn{2}{c}{ Rasa } & \multicolumn{2}{c}{ Warna } & \multicolumn{2}{c}{ Aroma } \\
\cline { 2 - 7 } & Rerata & $\begin{array}{c}\text { Jumlah } \\
\text { pangkat }\end{array}$ & Rerata & $\begin{array}{l}\text { Jumlah } \\
\text { pangkat }\end{array}$ & Rerata & $\begin{array}{l}\text { Jumlah } \\
\text { pangkat }\end{array}$ \\
\hline $\mathrm{A}_{20}$ & $3,9 \pm 0,67$ & $26,5 \mathrm{a}$ & $3,5 \pm 0,67$ & $29,0 \mathrm{~b}$ & $3,4 \pm 0,51$ & $27,0 \mathrm{c}$ \\
$\mathrm{A}_{25}$ & $3,8 \pm 0,58$ & $25,5 \mathrm{a}$ & $3,3 \pm 0,45$ & $26,5 \mathrm{~b}$ & $3,2 \pm 0,58$ & $23,5 \mathrm{c}$ \\
$\mathrm{A}_{30}$ & $3,5 \pm-0,52$ & $20 \mathrm{a}$ & $2,5 \pm 0,52$ & $16,0 \mathrm{~b}$ & $3,1 \pm 0,51$ & $21,5 \mathrm{c}$ \\
\hline
\end{tabular}

Keterangan: angka yang diikuti oleh huruf yang sama pada kolom yang sama berarti berbeda tidak nyata

Untuk parameter warna panelis memberikan skor nilai terendah pada konsentrasi gula pasir $30 \%$ yaitu 2,50 sedangkan skor tertinggi pada konsentrasi gula pasir $20 \%$ yaitu 3,5 (kuning). Hal ini sesuai dengan Phisut (2012) yang menyatakan bahwa penambahan konsentrasi bahan pengisi akan mengyebabkan bubuk sari buah kehilangan warna aslinya. Dari hasil uji organoleptik kesukaan panelis terhadap bubuk sari buah mangga terlihat bahwa panelis lebih menyukai perlakuan penambahan 20\%. Uji FreedmanConover menunjukkan bahwa pengaruh konsentrasi gula tidak signifikan terhadap tingkat kesukaan warna bubuk buah mangga. Tabel 1 menunjukkan bahwa perlakuan penambahan $20 \%$ berbeda tidak nyata dengan perlakuan penambahan gula $25 \%$ dan $30 \%$.

Untuk parameter aroma panelis memberikan skor nilai terendah pada konsentrasi gula pasir $30 \%$ yaitu 3,1 sedangkan skor tertinggi pada konsentrasi gula pasir $20 \%$ yaitu 3,4 (aroma mangga). Dari hasil uji organoleptik kesukaan panelis terhadap bubuk sari buah mangga terlihat bahwa panelis lebih menyukai perlakuan penambahan $20 \%$. Uji FreedmanConover menunjukkan bahwa pengaruh konsentrasi gula tidak signifikan terhadap tingkat kesukaan aroma bubuk buah mangga. Tabel 1 menunjukkan bahwa perlakuan penambahan $20 \%$ berbeda tidak nyata dengan perlakuan $25 \%$ dan $30 \%$.

\section{KESIMPULAN}

Pembuatan bubuk sari buah mangga instan untuk industri rumah tangga dapat dilakukan menggunakan proses penjemuran dan penambahan gula pasir sebagai bahan pengisi. Semua bubuk sari buah mangga yang dihasilkan memenuhi persyaratan kadar air dan ALT SNI 01-4320-1996. Dari aspek ekomi dan sensoris maka perlakuan terbaik yang direkomendasikan adalah perlakuan penambahan gula pasir 25\%. Bubuk sari mangga instan perlakuan penambahan gula $25 \%$, memberikan rendemen $32,76 \pm 1,6 \%$ kadar air $2,9 \pm 0,352 \%$, kadar asam askorbat $1,76 \pm 0,16 \%$, dan ALT $68 \pm 11$ cfu. Sifat sensoris bubuk sari buah mangga pada perlakuan penambahan gula $25 \%$ yaitu rasa 3,8; warna 3,3 dan aroma 3,2.

\section{SARAN}

Perlu dilakukan penelitian dengan menggunakan bahan pengisi lain seperti dekstrin, $\mathrm{cmc}$ dan teknologi pengeringan pembusaan (foam mat drying).

\section{UCAPAN TERIMA KASIH}

Penulis mengucapkan terima kasih pada Pimpinan Baristand Industri Palembang yang telah memfasilitasi terlaksananya kegiatan penelitian ini.

\section{DAFTAR PUSTAKA}

BeMiller, J.N., and Whistler, R.L.(2008). Carbohydrates in Fennema O.R. Foods Chemistry. University of Wisconsin Madison, Marcel Dekker Inc, New York, Basel, Hongkong.

Chong, C.H., dan Law, C.L (2011). Drying Of Exotic Fruits In Jangam SV, CL Law Dan AS Mujumdar. Drying Of Foods, Vegetables And Fruits. Volume 2, 2010, ISBN - 978-981-086759-1, Singapore. 
Endang, S.S dan Prasetyastuti. 2010. Pengaruh Pemberian Juice Lidah Buaya (Aloe vera L.) terhadap Kadar Lipid Peroksida (MDA) pada Tikus Putih Jantan Hiperlipidemia. Jurnal Farmasi Kedokteran. 3(1):353-362.

Gianti, I., dan Evanuraini,H. (2011). Pengaruh Penambahan Gula Dan Lama Penyimpanan Terhadap Kualitas Susu Fermentasi. Jurnal IImu dan Teknologi Hasil Ternak, 6(1) : 2833.

Gregory III, J.F.(2017). Vitamins. in Fennema O.R. Foods Chemistry. University of Wisconsin Madison, Marcel Dekker Inc, New York, Basel, Hongkong.

Harris GK, Marshall MR (2017) Ash analysis, Ch. 16. In: Nielsen SS (ed) Food Analysis, 5th edn. Springer, New York

Hii, C.L., Ong,S.P., dan Law, C.L. (2011). Drying Studies Of Tropical Fruits Cultivated In Malaysia: a review, Journal Of Applied Sciences 11(24):3815-3820.

Leghari, M.H., Sheikh, S.A., Kumbhar, M.B., danBaloch,A.F.(2013). Mineral Content in Dehydrated Mango Powder. Journal of Basic \& Applied Sciences, 9: 21-25.

Miller, D.D.(2008). Minerals. in Fennema O.R. Foods Chemistry. University of Wisconsin Madison, Marcel Dekker Inc, New York, Basel, Hongkong.

Nadirah, S. (2009). Production Of Mangifera Indica Powder Using Spray Dryer And The Effect Of Drying On Its Physical Properties. Thesis Faculty of Chemical and Natural Resources Engineering, University Malaysia Pahang.

Phisut, N.(2012). Spray Drying Technique Of Fruit Juice Powder: Some Factors Influencing The Properties Of Product. International Food Research Journal 19(4):1297-1306.

Simanjuntak, P.T.(2014). Komponen Gizi dan Terapi Pangan Ala Papua. Deepublish, Yogjakarta.

Sulfiani, Sukainah dan Mustarin, A.(2017).

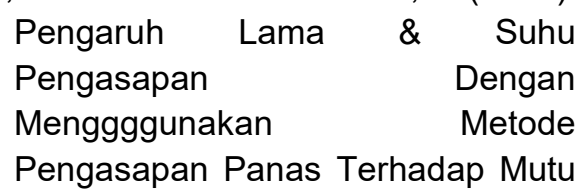

Ikan Lele Asap. Jurnal Pendidikan Teknologi Pertanian, 3 :S93-S101.

Yunita, M., Hendrawan, Y dan Yulianingsih, R.(2015). Analisis Kuantitatif Mikrobiologi Pada Makanan Penerbangan (Aerofood ACS) Garuda Indonesia Berdasarkan TPC (Total Plate Count) Dengan Metode Pour Plate. Jurnal Keteknikan Pertanian Tropis dan Biosistim 3(3): 237-248.

Wong, C.W., Pui, L.P., dan Ng, J.M.L. (2015). Production Of Spray-Dried Sarawak Pineapple (Ananas Comosus) Powder From Enzyme Liquefied Puree. International Food Research Journal 22(4):1631-1636.

Varvara, M., Bozzo, G., Celano, G., Disanto, C., Pagliarone, C. N., \& Celano, G. V. (2016). The Use of Ascorbic Acid as a Food Additive: Technical-Legal Issues. Italian Journal of Food Safety, 5(1), 4313. 
